\title{
Technology, Financial Innovations and Bank Behavior in a Low Income Country
}

\author{
Alex Bara*1, Pierre LeRoux ${ }^{2}$ \\ ${ }^{*}$ Agricultural Bank of Zimbabwe, Zimbabwe \\ ${ }^{2}$ Department of Economics, Nelson Mandela University, South Africa \\ alexabara15@gmail.com
}

\begin{abstract}
Technology has enabled banks to introduce new products that integrate markets, simplify operations and enable expansion of business at low cost, expand to new markets, take new risks and deepen their markets. Zimbabwe registered significant growth in adoption and diffusion of financial innovations over the past two decades, which coincided with a shift in the structure of credit portfolios of banks, and growth in credit as well as risk appetite. This study empirically evaluates the impact of financial innovations in influencing bank behaviour, specifically, portfolio structure risk appetite and delivery channels of banks in Zimbabwe. The study applied co-relational analysis, Fully Modified OLS and the Dynamic OLS estimation models as well as Autoregressive Granger causality approaches. Empirical results show that technology has the capacity to influence activities of banks in risk management, credit and delivery of banking service in lowincome countries. Precisely, financial innovation influences increase in credit towards previously high-risk areas, compositions of credit portfolios in banks and support growth in number of bank accounts. Causality was found to run from financial innovation to bank behaviour, and only in the long run.
\end{abstract}

Keywords: Financial Innovation, Technology, Banks, Zimbabwe

\section{Introduction}

The proliferation of information communication technology in banking enables financial innovations that influence dynamic changes in the behaviour of banks. Financial innovation involves crafting and popularizing new financial instruments, technologies, institutions, markets, procedures and business models including the new application of existing ideas in a different market context (Lerner \& Tufano, 2011). Technology has enabled banks to introduce new products that integrate markets, simplifying operations and enable expansion of business at low cost. Through financial innovations, technology has created opportunities for banks to expand to new markets, take new risks, introduce new products and deepen their markets thereby redefining portfolio balance of banks. In developing markets, the last decade has seen a proliferation of innovative financial services targeted at the unbanked populations (Denyes \& Lonie, 2016). Development of innovations supports increased credit by banks given improved credit scoring, monitoring, data processing and evaluation of borrowers. In respect of risk, financial innovation, on the one hand, reduces risk on some banks products and markets, allowing a reduction in risks and costs, resulting in enhancement in services (Arnaboldi \& Rossignoli, 2013). On the other hand, it results in the emergence of new risks and increased the risk of some portfolios (Matthews \& Thompson, 2008).

The influence of financial innovation on bank behaviour has also been evident in Zimbabwe. In Zimbabwe, there has been significant adoption and diffusion of financial innovations over the past two decades, with major innovation having been visible in the last nine years. Coincidentally, over the same period there has been a shift in the structure of credit portfolios of banks, with growth in credit in sectors that were previously regarded as high-risk areas. Clear examples have been growth in consumer/household lending from 1.3\% of total credit in March 2009 to 22.2\% in March 2017 (RBZ, 2017). In addition, banks began to expand into previously marginalised areas through microfinance activities and to adopt non-traditional delivery channels including digital channels. Banks are making a significant investment in technology, particularly to expand delivery models including mobile banking, agency banking, the point of sale (POS) and internet banking. Banks are also significantly driving adoption of plastic money and use of non-cash payment systems for transactions. The Reserve Bank of Zimbabwe statistics showed that transactions on the point of Sale, which uses debit cards, increased by 736.7\% from USD $\$ 55.8$ million in January 2011 to USD $\$ 466.9$ million in May 2017. Mobile money transactions grew by $3372 \%$ from US $\$ 23.5$ million in January 2011 to US\$ 792 million in

\footnotetext{
${ }^{1}$ Agricultural Bank of Zimbabwe
} 
May. This growth was driven not only by the obtaining cash shortages of liquidity challenges, but as a strategy to enhance growth in business. Banks have also been changing their business models and the structure of their institutions. Banks are getting thinner on branch network, whilst increasing footprint through agencies and on mobile platforms. Literally, bank behaviour is gradually shifting, due to innovations. Preliminary assessment indicates that the new financial products in banking, the changes in risk appetite, expansion of delivery channels and business expansion in banking in Zimbabwe all came as a result of positive developments and reaction to challenges in the economy. Notwithstanding the effects of economic changes in the country, intuition suggests that technology and financial innovations have also enabled and supported this dynamic shift in the conduct of Zimbabwean banks. This study empirically evaluates the impact of financial innovations in influencing bank behaviour, specifically, portfolio structure, risk appetite and delivery channels of banks in Zimbabwe. The study contributes to the literature on financial innovations and risk-taking behavior of banking and structural transformation of banks. Literally, the study essentially evaluates the role of innovations and technology in influencing the future of banking.

Technology and Financial Innovations in Zimbabwe: Zimbabwe has been keeping pace with other developing countries in embracing technology and in the adoption and introduction of financial innovations in banking. For instance, the country was also among the first countries in Southern Africa to introduce computers in banking in the 1950s, to have ATMs in the early 1990s, and lately mobile banking among other fin tech products. Historically, the country's adoption and the introduction of financial innovations, in the 1970 s and 1980s, was limited, presumably due to a closed financial system, with the "diffusion gap" (crosscountry effects) being over 20 years (Bara, 2017). The international financial institutions played a big role in introducing and supporting innovation in the Zimbabwean banking sector. The financial liberalisation which occurred in the 1990s triggered the expansion of the financial sector, resulting in the emergence of local banks and financial institutions. This brought competition in the market and smaller banks, predominantly indigenous, had to look beyond ordinary banking practice for survival. These banks became more aggressive in financial innovation, embracing new technology and introducing new products in order to remain competitive.

Fundamentally, the openness of Zimbabwe's financial sector following financial liberalisation enabled increased penetration of innovations (Bara, 2017). Financial innovation slowed down during the period from 2000 to 2008 when the country underwent a phase of economic decline. During the period, the country's financial system was affected by hyperinflation that resulted in the loss of value of the country's currency. As such, the introduction and adoption of new products was minimal as banks concentrated on survival. For example, innovative products such as derivatives that had been introduced to the market in the late $90 \mathrm{~s}$, were discontinued. A number of savings products in banks were discontinued as the value of savings were eroded by inflation. Zimbabwe officially abandoned its domestic currency in February 2009 following the period of economic decline from 2000-2008, following the collapse of the domestic currency (RBZ, 2010). The country replaced its currency with a basket of hard currencies under a system called 'multicurrency' and managed to contain the hyperinflation and stimulated economic activity. After the introduction of the multicurrency system, the banking sector recorded some positive developments, which included a rapid growth in financial innovation, adoption of modern technology in banking and rolling out of delivery channels such as mobile and agency banking, POS machines, Straight Through Process (STP) systems.

The country also joined the SADC Integrated Regional Electronic Settlement System (SIRESS) system, and began processes of implementing to Basel 2, among other developments. The sector also recorded growth in credit, deposit, and subsequently profitability and capitalisation of some banks. Due to competition, in the first 2 years of dollarization (multicurrency system), banks aggressively expanded lending in order to increase their market share. Also due to increased mechanisms of monitoring borrowers and reduced KYC requirements, banks began to expand into consumer lending, which previously was considered high risk. Banks also had to invest in technology, with some introducing microfinance in their portfolios, to target the consumer market, partly as a result of a decline in corporate business as capacity utilization in the manufacturing sector receded. To attract business, banks began issuing medium to long-term loans, but these were financed by short-term deposits and lines of credit. The disproportionate lending by banks resulted in the growth of non-performing loans on banks loans and the challenge was compounded as more medium to long-term loans were maturing. 
The non-performing loans (NPLs) reach a peak of 20.1 per cent in September 2014 from a low rate of 1.8 per cent recorded in Feb 2009. These non-performing loans were mainly driven by the high cost of borrowing in the market, aggressive lending by banks on the back of weak credit risk management including inappropriate loan structuring, the absence of robust credit reference systems and governance issues particularly insider loans (RBZ, 2013). A number of banks also faced challenges emanating from the tight capital requirements, liquidity challenges and a general slowdown in the economic environment, which affected a number of banks. Resultantly, some banks collapsed, other banks resized, adjusting to shrinking macroeconomic environment, increasing NPLs and declining business. However, during the same time, a number of banks invested in delivery channels, including mobile banking and POS machines and began rolling out agency banking as measures to expand business at low cost. Banks were also expanding delivery channels, and started to offer credit to previously risky areas whilst de-risking in other traditional sectors. These and many other new innovations seemingly influenced bank behaviour, particularly on risk appetite, institutional structures and business focus. It is, therefore, not clear whether the change in strategy by banks was driven by technology, financial innovations or other factors and considerations. What is observable, though, is that there has been a gradual increase in the adoption of new innovations by the banking sector in Zimbabwe in recent years.

\section{Literature Review}

(Utterback \& Afuah, 1998) views innovation as the use of technical knowledge to offer new products and service that the market wants. Financial innovations comprise technological advances that enable access to information, trading and support varying forms of payment (Solans, 2003). (Frame \& White, 2004) and (Lewis \& Mizen, 2000) relate the presence of financial innovation to the changing needs of customers, circumstances of providers, market conditions, policies and technology. (Laeven, et al., 2015) explain that financial innovation is not only restricted to the invention of new financial products and instruments, or financial institutions, but also includes financial improvements in data processing and credit scoring that enhances evaluation of borrowers by banks (Laeven, et al., 2015). Innovation permits reduction in costs and risk as well as an improvement in services (Arnaboldi \& Rossignoli, 2013). Financial innovation is driven by the need to establish new and effective ways of increasing profitability by market participants (Bilyk, 2006). In respect of risk, on one hand financial innovation reduces risk on some banks products and markets, including credit risk. On the other hand, financial innovation has resulted in the emergence of new risks and increasing risk on some portfolios.

By allowing new products and activities on their portfolios, banks also expose themselves to new risks associated with the provision of this service (Matthews \& Thompson, 2008). The Consultative Group to Assist the Poor (CGAP) pointed out that implementing digital financial services come with new risks that are beyond operational and technical risks. Financial innovation thus forces banks to redefine their risk management strategies, shifting risk preferences and in the process influencing the risk-behaviour of banks (Denyes \& Lonie, 2016). Banks decisions in a regulated banking sector are heavily influenced by financial innovation (Kero, 2013). Banks achieve improvements in the costs and capacity of lending due to improvements in "back-office" technologies, whilst consumers benefit from improved "front-office" technologies (Berger, 2003). Effective financial innovations reduce costs and risks of service and also provide enhanced services to users. The advancing technology is permitting new financial products and effective risk management systems, while removing bias on varying approaches that enhance decisions by risk managers (Harle, et al., n.d). Technology, mainly mobile phones and networks of agents, is enabling previously excluded low-income individuals, microenterprises and marginalised people access financial services (Denyes \& Lonie, 2016).

(Berger, 2003) Indicted that banks use financial technologies to create and value new securities, assess the distribution of returns, and in making decisions on portfolios. For examples, banks employ financial engineering to generate new financial products such as derivatives, risk models that are applied to the management of exposure, and design modern credit scoring and to assess credit requests (Berger, 2003). Financial innovations are also reshaping the banking processes, and the structure of financial institutions. (Llewellyn, 2009) noted that financial innovation driven instruments meant to alter credit risk produced new banking models that changes banking in an essential way. Customers' anticipations of banking services are changing with the emergence and evolvement of technology and new business models (Harle, et al., n.d). 
Financial innovations, trusted by the growing ownership in mobile and smartphones, are reshaping the customer experience and transforming customer expectations, forcing banks to continuously invest in core systems and processes (Ernst\&Young, 2015). In today's banking industry, varied and satisfying experience by the customer has become more important than the mere provision of financial services (Kamra, 2014). (Ernst\&Young, 2015) Projected that the cost of banking services in emergent markets would decrease considerably, with mobile penetration rates increased significantly, if biometric security enabled mobile wallets to become the standard. The functions of retail banking, as well as relationship managers in banking, will be changed by technology as technology-based interfaces are increasingly used (Ernst\&Young, 2015). Financial engineering could assist with decomposition, transferring and pooling of risks in line with the risk appetite of lenders and improve the existing options for managing risk (Jenkinson, et al., 2008). The desired risk appetite helps facilitate business portfolio decisions based on a comparison of risk-return profiles (Hyde, et al., 2009). Technical progression could support the growth of bank sizes through the creation of new services that enhances scale economies and by facilitating consolidation (Berger, 2003).

Technology would also drive the geographic expansion of banks beyond the scale effects of bank expansion (Berger, 2003). The institutional structural changes and change in banking processes are also triggered by disruptions that banks are now facing, mainly driven by innovation in information technology. New gadgets and devices are affording various customer touch points with banking, providing an information trail that banks should use to move their bottom line upwards (Kamra 2014). Banks face renewed competition in facilitating transactions, particularly transfers and payments driven by IT corporations, and are forced to react to the competition (Khayrallah, et al., 2015). In support of this argument, (Khayrallah, et al., 2015) noted that in the developing countries, nearly three billion people depend on mobile telecom operators, rather than banks, to manage their funds. A fin tech expert with KPMG Ireland pointed out that banks are prioritising investment in own technologies, mainly innovations in payments and lending, ahead of exterior start-ups (Cogley, 2016). Such investments are in line with the need to reduce operating cost, and subsequently reducing staffing levels (Cogley, 2016).

Regarding risk management, technology and financial innovations brings in two dimensions, where on one end banks are able to manage risk due to technology. On the other end, technology is bringing in new sophisticated risks, some of which banks are not able to anticipate and manage upfront, resulting in crises. Financial innovation in the banking sector increases the demand for risk management techniques in the primary and secondary markets (Kero, 2013). Growth in the degree of financial innovation enables banks to better hedge their idiosyncratic risk and exposing them to less total risk in their investment and therefore increase their inclination towards acquiring riskier assets (Kero, 2013). The increased appetite for risk would push banks to even venture into other portfolios which were considered un-bankable, thereby changing the portfolio balance. For example, financial innovation increases the demand for credit derivatives as they inevitably become better and efficient instruments for hedging of risk (Kero, 2013). Financial innovations, with the ability to pool and transfer risk, are capable of insulating the financial systems against negative shocks, thus can be used for effectively improving risk management (Jenkinson, et al., 2008).

Ordinarily, financial risks are generally categorized as credit, liquidity and interest rate risk as these relate to the management of a banks' balance sheet. (Beyani \& Kasonde, 2005) opinioned that sophisticated structured products such as derivatives have resulted in banks being increasingly exposed to other risks, such as, market and operational risk. Banks may assume significant risks when they engage in a complex structured finance transaction (Bies, 2004). (Harle, et al., n.d) added that risk functions of banks would also have to cope with the evolution of newer types of risks brought by technology, including cyber risk, contagion risk and model risk, and, all of which demand new skills and tools to management. Innovations in credit risk management, including credit default swaps and synthetic collateralized debt obligations are some of the complex structured finance transactions introduced recently (Bies, 2004). Risk often increases exponentially with changes in technology, but generally bankers are sluggish in adjusting their perception of risk (Greuning \& Bratanovic, 2003). Implicitly, the market's is thus capable of being innovative than understanding and accommodating the accompanying risk (Greuning \& Bratanovic, 2003). The empirical literature also supports the effect of financial innovations and technology on bank behaviour, particularly risk-taking behaviour. (Norden, et al., 2014) finds out that banks with significant credit derivatives charge considerably low corporate loan margins, and the banks' net positions are not linked to loan pricing. 
In addition, they also establish that such banks reduce their lending much less than other banks during the crisis and always have lower loan charges (Norden, et al., 2014). The innovation ignited a global financial crisis and this caused a shift in the risk functions. These included additional requirements in the capital, liquidity, and funding, as well as higher standards for reporting risk (Harle, et al., n.d). Innovation has also driven the development of complex structured finance transactions that may expose the financial institution to elevated levels of risk (Bies, 2004). The management of other risks outside the financial sector became more essential as the standards for compliance and conduct tightened (Harle, et al., n.d). (Kero, 2013) showed how financial innovation explains the strong growth in primary and secondary credit markets in the US, since the 1990s. In addition, (Kero, 2013) observed that financial innovation enables banks to reduce the risk through investing in credit derivatives in the secondary markets. Their study results show that financial innovation increases bank appetite for risky investment, credit derivatives acquisition and the portfolio variance (Kero, 2013). A study by (Irungu, 2014) revealed that financial innovations, that is, institution, product and process innovations- have a positive effect on management of credit risk of commercial banks in Kenya. Findings by (Santomero \& Trester, 1998) insinuate that the risky asset portfolio held by banks explicitly increases due to innovations. (Iman, 2011) concluded that the market and other banks play an important role in influencing the adoption of e-banking services and, that, innovation and dynamism are mostly driven by smaller and newer banks than bigger and older banks.

\section{Methodology and Data}

Various studies use different approaches and methodologies to assess the impact of technology on banks. This study applies a quantitative approach to estimate the effect of technology and financial innovation on bank behaviour in line with (Norden, et al., 2014), (Irungu, 2014) and (Kero, 2013). (Norden, et al., 2014) used a standard loan pricing model, expressed as a general linear regression model to assess the effect of credit derivative on loan interest margins. (Kero, 2013) estimated a linear regression model, and add the Constant Absolute Risk Aversion (CARA) Normal specification of the model that permits generation of closedform expressions for the demand of risky assets and for the demand of credit derivatives. (Brandon \& Fernandez, 2005), (Beyani \& Kasonde, 2005) and (Irungu, 2014) used qualitative approach using narratives to review how credit derivatives affect risk management. The study used dynamic and fully modified ordinary least squares approaches to estimate the link between financial innovations and bank behaviour. The paper also applied ordinary covariance analysis, testing the strength of the correlations between financial innovation index and variables that measure bank behaviour (bank credit- total and to individuals, branches and bank accounts). Correlation quantifies the extent to which two quantitative variables, move in sync. The Spearman's rank order test was used as it applies to non-linear relationships and disregards the distribution of the variables (Hauke \& Kossowski, 2011).

Model Specification: The study model departs from the basic linear financial model that relates financial innovation to the financial outcome as below:

$y=\alpha+\beta f+\gamma X+\varepsilon$

where $y$ is bank behaviour outcome, $f$ is a vector of financial innovation and technology measures, $\boldsymbol{X}_{\boldsymbol{i}}$ is a matrix of control variables. This study model framework as outlined in equation (2) below.

$B B=\alpha+\beta F I I+\gamma X+\varepsilon$

Where $B B$ is bank behaviour variables, which are be represented by adversely classified loans denoting credit risk; domestic credit to private sector and credit to individuals denoting credit portfolios; bank accounts representing business growth; and bank branching capturing delivery channel. $X$ a set of control measures, $F$ is a vector of financial innovation and technology measures proxied by a Financial Innovation Index (constructed from integration of values transacted through Automated Teller Machines, the Internet, Point of Sale machines, Mobile Banking, Electronic Transfers and Cheques), whilst, $\varepsilon$ is the error term, and $\alpha, \beta$ and rare parameters to be estimated. 
$\left[\begin{array}{c}A C L_{-} T L \\ C R \\ I N D \\ B N K A C C \\ B R N C H\end{array}\right]=\alpha_{i}+\beta_{i}[F I I]+\gamma_{i}\left[\begin{array}{c}L I Q \\ N I M \\ G G D P \\ D T A \\ L T D\end{array}\right]+e_{i}$

where:

ACL_TL is Adversely Classified Loans to Total Loans

$\boldsymbol{C R}$ is Domestic credit to Private Sector

IND is credit to individual borrowers

BNAKACC is Bank Accounts

BRNCH is Bank branches
FII is Financial Innovation Index

To estimate this model, the study runs three estimation models, the Ordinary Least Squares (OLS), the Fully Modified OLS (FMOLS) and the Dynamic OLS (DOLS). The rationale is that OLS estimators contain the 'second-order bias despite the estimators being consistent in the presence of a serial correlation in the error term and/or a correlation between the regressors and co-integration errors. To deal with this problem, the study runs Phillips and Hansen (1990)'s Fully modified least squares (FMOLS) estimator and (Stock \& Watson, 1993)'s Dynamic Least Squares (DOLS). Besides, given that a few variables are stationary in difference when most variables are stationary in levels, co-integrating regressions (the FMOLS and DOLS) would be ideal to establish a long run relationship. FMOLS was designed by (Phillips \& Hansen, 1990) to provide optimal estimates of co-integrating regressions. Based on Monte Carlo simulations, the FMOLS method is suitable for small samples as it produces reliable estimates and is able to test for robustness. The method also changes least squares to account for the endogeneity in the regressors and for serial correlation effects that result from the existence of a co-integrating relationship (Phillips \& Hansen, 1990).In other words, DOLS can obtain efficient estimators for the co-integrating vectors involving deterministic components and accommodates varying orders of integration (Stock \& Watson, 1993) and also account for possible simultaneity within regressors (Masih \& Masih, 1996).

Granger Causality: Causality test was performed to establish the direction of causality between bank behaviour and financial innovation. The Granger causality means past values of the independent and the dependent variables help in explaining future values of the dependent variable. The set of equations for testing the Granger Causality test using an autoregressive approach can be represented as follows: -

$$
\begin{gathered}
\mathrm{BB}_{\mathrm{t}}=\sum_{\mathrm{i}=1}^{\mathrm{n}} \alpha_{\mathrm{i}} \mathrm{FI}_{\mathrm{t}-\mathrm{i}}+\sum_{\mathrm{j}=1}^{\mathrm{n}} \beta_{\mathrm{j}} \mathrm{BB}_{\mathrm{t}-\mathrm{j}}+\mathrm{u}_{1 \mathrm{t}} \\
\mathrm{FI}_{\mathrm{t}}=\sum_{\mathrm{i}=1}^{\mathrm{n}} \lambda_{\mathrm{i}} \mathrm{FI}_{\mathrm{t}-\mathrm{i}}+\sum_{\mathrm{j}=1}^{\mathrm{n}} \delta_{\mathrm{j}} \mathrm{BB}_{\mathrm{t}-\mathrm{j}}+\mathrm{u}_{2 \mathrm{t}}
\end{gathered}
$$

Equation 4 represents an auto-regressive (AR) model that was converted to an auto-regressive model of order 2 (AR (2)) by setting $\mathrm{n}$ equal to two (Bara, et al., 2016). The lagged dependent variable under explanatory variables is meant to capture self-propelling causality effects. A test for Granger causality in a panel model tests the significance of $\alpha_{1}=\alpha_{2}=0$ and $\lambda_{1}=\lambda_{2}=0$ using a $\chi^{2}$ with two degrees of freedom (Caporale, et al., 2009). This study runs the restriction of $\alpha_{1}+\alpha_{2}=0$ and $\lambda_{1}+\lambda_{2}=0$ to test for the long-run linkage between bank behaviour and financial innovation.

Data and Variables: The paper uses quarterly data for Zimbabwe, covering the period 2009 to 2016. The data were obtained from the Zimbabwe Statistical Agency and Reserve Bank of Zimbabwe. Measures used to capture bank behaviour were selected to represent credit risk behaviour (adversely classified loans as a proportion of total loans), portfolio preference of banks (domestic credit and credit to individuals as a proportion of total credit) as well as bank behaviour on delivery channel (branches) and business expansion (bank accounts). The definition of the variables used in this study are shown below, (Table 1). 


\begin{tabular}{|c|c|c|}
\hline \multicolumn{3}{|c|}{$\begin{array}{c}\text { Journal of Economics and Behavioral Studies (ISSN: 2220-6140) } \\
\text { Vol. 10, No. 4, pp. 221-234, August } 2018 \\
\end{array}$} \\
\hline \multicolumn{3}{|l|}{ Table 1: Variables and Description } \\
\hline Variable Category & Variable & Description \\
\hline \multirow{5}{*}{$\begin{array}{l}\text { Dependent } \text { Variables- Bank } \\
\text { Behaviour }\end{array}$} & ACL_TL & Adversely Classified Loans to Total Loans \\
\hline & $\mathrm{CR}$ & Credit to the domestic private sector \\
\hline & IND & Bank credit to individuals as a proportion of total credit \\
\hline & BRNCH & Bank branches per 100000 adults \\
\hline & BNKACC & Bank accounts per 1,000 adults \\
\hline \multirow[t]{6}{*}{ Financial Innovation Index (FII) } & ATM & Values transacted through Automated Teller Machines \\
\hline & Internet & Values transacted through the Internet \\
\hline & POS & Values transacted through the Point of Sale machines \\
\hline & Mobile & Values transacted through the Mobile Banking \\
\hline & ZETSS & Values transacted through the Electronic Transfer \\
\hline & Cheque & Values transacted through the Cheque \\
\hline \multirow[t]{6}{*}{ Control Variables } & GGDP & Growth in Gross Domestic Product \\
\hline & NIM & Net Interest Margin \\
\hline & CAR & Capital Adequacy Ratio \\
\hline & LIQ & Liquidity ratio \\
\hline & DTA & Deposit to Total Assets \\
\hline & LTD & Loan to Deposit \\
\hline
\end{tabular}

The Composite Financial Innovation Index (FII): Financial innovation was presented as an index of a number of variables that measure financial innovation products and processes combined together using the Principal Component Analysis (PCA) approach. Using the PCA, the FII was created using six variables namely values transacted through Automated Teller Machines, Internet, Point of Sale machines, Mobile Banking, Electronic Transfer and Cheques. The purpose of a composite index was to combine the effect of the various measures of financial innovation on bank behaviour. To establish this, a weighted linear combination of the original values was formulated with the weights being the set of uncorrelated principal components of the original variables. Thus the principal components for $n$ set of variables from $\boldsymbol{X}_{1}, \boldsymbol{X}_{2}, \ldots \boldsymbol{X}_{n}$, would be as follows (Jolliffe, 2002):-

$$
P C_{i}=\sum_{i=1}^{n} a_{i} X_{i}=a_{1} X_{1}+a_{2} X_{2}+\cdots+a_{n} X_{n}
$$

$\boldsymbol{P} \boldsymbol{C}_{\boldsymbol{i}}$ is the principal component, $\boldsymbol{a}_{\boldsymbol{i}}$ represents the linear weights and $\boldsymbol{X}_{\boldsymbol{i}}$ is the matrix of correlated variables of interest. In this case, three PC extracts will be generated from the original six variables and ordered in such a way that the first PC explains the largest amount of variation in the data (Jolliffe, 2002). The order in this study was determined by volume of transactions of the innovation. The composite index was then calculated from the six principal components from the first principal component contains the largest amount of information common to all of the variables of interest.

$$
\text { FII }=a_{1} \text { ZETSS }+a_{2} \text { Mobile }+a_{3} \text { POS }+a_{4} A T M+a_{5} \text { Internet }+a_{6} \text { Cheque }
$$

Stationarity Tests: The stationarity or otherwise of a series can strongly influence its behaviour and properties - e.g. persistence of shocks will be infinite for non-stationary series. If two variables are trending over time, a regression of one on the other could have a high R2 even if the two are totally unrelated, leading to spurious regressions. If the variables in the regression model are not stationary, then the standard assumptions for asymptotic analysis would not be valid. The study carried out a stationarity test and results are presented in Table 2. 


\begin{tabular}{l} 
Journal of Economics and Behavioral Studies (ISSN: 2220-6140) \\
Vol. 10, No. 4, pp. 221-234, August 2018 \\
\hline \hline
\end{tabular}

Table 2: Stationarity Tests

\begin{tabular}{lll}
\hline Variable & Augmented Dickey-Fuller test statistic & Level of Stationarity \\
\hline ACL_TL & $-4.7207^{* * *}$ & $\mathrm{I}(0)$ \\
BNKACC & $-2.9977^{* *}$ & $\mathrm{I}(0)$ \\
BRNCH & $-5.7688^{* * *}$ (intercept and trend) & $\mathrm{I}(0)$ \\
CAR & $-2.7051^{*}$ & $\mathrm{I}(0)$ \\
CR & $-3.3715^{* *}$ & $\mathrm{I}(0)$ \\
DTA & $-3.7473^{* * *}$ & $\mathrm{I}(0)$ \\
FII & $-2.8005^{* *}$ (intercept and trend) \\
GGDP & $-5.3917^{* * *}$ (intercept and trend) \\
IND & $-2.7002^{*}$ & $\mathrm{I}(0)$ \\
LIQ & $-3.6653^{* * *}$ & $\mathrm{I}(0)$ \\
LTD & $-3.8389^{* * *}$ & $\mathrm{I}(0)$ \\
NIM & $-2.7438^{*}$ & $\mathrm{I}(0)$ \\
\hline
\end{tabular}

Variables are stationary in levels except for bank branches, GDP and Financial Innovation index which is level stationary in trend and intercept (Table 2). As such, the study employs co-integration regression approaches, FMOLS in line with (Phillips, 1995) and DOLS to estimate the long-run effects of financial innovation on bank behaviour.

\section{Findings and Discussion}

Correlation Analysis: Results in Table 3 indicates a positive correlation between financial innovation and bank credit; credit to individuals; bank branches; and bank accounts. Financial innovation is, however, negatively related to Adversely Classified Loans.

Table 3: Correlation Analysis between Financial Innovation and Bank Behaviour Variables

\begin{tabular}{|c|c|c|c|c|c|c|}
\hline \multicolumn{7}{|c|}{ Covariance Analysis: Ordinary } \\
\hline Probability & ACL_TL & CR & IND & BNKACC & BRNCH & FII \\
\hline ACL_TL & 1 & & & & & \\
\hline CR & $0.4914^{* * *}$ & 1 & & & & \\
\hline IND & $0.4841^{* * *}$ & $0.9615^{* * *}$ & 1. & & & \\
\hline BNKACC & 0.023831 & $-0.3804^{* *}$ & $-0.3471^{*}$ & 1. & & \\
\hline BRNCH & 0.261258 & $0.9423^{* * *}$ & $0.9085^{* * *}$ & $-0.4374^{* *}$ & 1. & \\
\hline FII & -0.190667 & $0.4939 * * *$ & $0.5489^{* * *}$ & 0.118311 & $0.5413^{* * *}$ & 1. \\
\hline
\end{tabular}

$*, * *, * * *$ statistically significant at $10 \%, 5 \%$ and $1 \%$, respectively

The correlation is, however, statistically significant for bank credit, credit to individuals, and bank branches. Indicatively, the results show that banks consideration of credit and branches are influenced by financial innovation. This result is in line with (Lerner \& Tufano, 2011) that financial innovation popularizes new financial instruments, technologies, institutions, markets, procedures and business models including the new application of existing ideas in a different market context. Consistent with results, in Zimbabwe, financial innovation enabled introduction of banking delivery and payment systems such as ATMs, Mobile Banking, Electronic payment systems and Point of Sale and Internet Banking, all of which were included in the financial index. As to what causes the other, this would require the application of econometric models to test the causal relationship.

Econometric Estimation Results: The study carried out econometric estimations on three broad areas, one to estimate the linkage between credit risk and financial innovation, second the relationship between credit portfolio and financial innovation and lastly between delivery channels as well as business expansion (bank accounts) and financial innovation. 
Credit Risk and Financial Innovation: Results in Table 4 shows that financial innovation generally impacts negatively on credit risk in banks. The negative impact of financial innovation on credit risk is statistically significant under Dynamic Ordinary Least Squares.

Table 4: Credit Risk and Financial Innovation

\begin{tabular}{llll}
\hline $\begin{array}{l}\text { Dependent Variable: ACL_TL } \\
\text { Exogenous variables }\end{array}$ & $\begin{array}{l}\text { Ordinary } \\
\text { Squares (OLS) }\end{array}$ & $\begin{array}{c}\text { LeastFully } \\
\text { Squares (FMOLS) }\end{array}$ & $\begin{array}{c}\text { Modified } \\
\text { LeastDynamic } \\
\text { (DOLS) }\end{array}$ \\
\hline Financial Innovation & -0.00009 & -0.000005 & $-0.0006^{* *}$ \\
Deposit to Total Assets & 0.0268 & -0.0122 & $-0.6439^{* *}$ \\
Domestic Credit & $0.0011^{*}$ & $0.0010^{* * *}$ & -0.0001 \\
Liquidity & $0.7450^{* * *}$ & $0.7452^{* * *}$ & $0.4825^{* * *}$ \\
Capital adequacy ratio & $-1.8168^{* * *}$ & $-1.8247^{* * *}$ & $-1.6242^{* * *}$ \\
Growth in GDP & 0.0001 & $0.0001^{* *}$ & -0.00007 \\
Constant & $0.1890^{* *}$ & $0.2157^{* * *}$ & $0.7185^{* * *}$ \\
R-sqd & 0.988092 & 0.983264 & 0.999538 \\
Adj R-sqd & 0.985234 & 0.979081 & 0.996765 \\
\hline
\end{tabular}

${ }^{*}, * *, * * *$ statistically sig at $10 \%, 5 \%$ and $1 \%$, respectively

Indicatively, the results suggest that in the long run, financial innovation reduces banks' credit risk, as shown by the dynamic OLS, as one of the co-integrating regressions, shows long-term effects. The results are in support of (Arnaboldi \& Rossignoli, 2013) that financial innovation reduces risk on some banks products and markets, including credit risk. The rationale could be that financial innovation is enhancing monitoring of borrowers, assist in credit management such that the number of adversely classified loans is reduced a financial innovation increase. The results could also be indicating that financial innovation is influencing banks towards introducing transactional and non-funded products than funded products, hence the gradual reduction in credit risk with improvement in technology. Financial innovation is bringing more of transactional income and banks become more reliant on non-funded income rather than funded income, particularly in the back of high NPLs in the sector.

Credit Portfolio and Financial Innovation: Results in Table 5 shows the outcome of estimations of the effects of financial innovation on banks' decision on credit portfolio. Econometric estimations indicate that financial innovation is statistically significantly linked to domestic credit under the DOLS model, where it results in a reduction in domestic credit (Table 5). The results, however, indicate that financial innovation has a relatively strong and positive effect on credit to individuals $(0.0128$ and 0.018 under OLS and FMOLS respectively). The result is consistent with (Berger, 2003) who noted that that banks use financial technologies to make portfolio decisions among other. And just as (Hyde, et al., 2009) noted that desired risk appetite helps facilitate business portfolio decisions based on a comparison of risk-return profiles, financial innovation by the bank in Zimbabwe pushed an increase in credit to individuals than total general credit, indicative of a shift in the portfolio and desired risks. The results are in line with (Kero, 2013) that growth in the degree of financial innovation enables banks to better hedge their idiosyncratic risk and acquire riskier assets. The fact that banks in Zimbabwe readjusted their credit portfolio and increased lending to individuals could have been influenced by the availability of technology and mechanism of managing risks associated with lending to individuals.

The use of financial innovation and technology to be able to monitor lending to previously high-risk areas of consumer lending have altered the banks' risk appetite for consumer lending. The availability of financial innovation to reach out to more individuals, coupled with high repayment rates by individuals, forces banks to increase consumer lending. The results thus are indicative of increased risk appetite for banks due to financial innovation. The results are indicative of the fact that financial innovation influences banks to redistribute credit from other sources towards individuals. In Zimbabwe, the growth in NPLs, before the introduction of ZAMCO, a special purpose vehicle created by the Reserve Bank of Zimbabwe to house bank NPLs, had driven most banks to reduce lending to productive sectors and increase lending to individual borrowers. Some of the borrowers classified as individuals would be entrepreneurs who are operating in the informal sector, as such financial innovation has enabled banks to be able to monitor them and hence tolerate 
risks in these sectors. As such, bank risk taking behaviour has been responsive to financial innovation. Also, the prevailing cash shortage has pushed up demand for plastic money and subsequently need for bank accounts by the general public. Banks had to invest in ICT systems and fin tech products in order to accommodate the increasing volumes as well as provide alternative payment platforms to counter the cash shortages.

Table 5: Credit Portfolio and Financial Innovation

\begin{tabular}{|c|c|c|c|c|}
\hline $\begin{array}{l}\text { Endogenous } \\
\text { variable }\end{array}$ & Exogenous variables & $\begin{array}{l}\text { Ordinary Least } \\
\text { Squares (OLS) }\end{array}$ & $\begin{array}{lr}\text { Fully } & \text { Modified } \\
\text { Least } & \text { Squares } \\
\text { (FMOLS) }\end{array}$ & $\begin{array}{l}\text { Dynamic Least } \\
\text { Squares } \\
\text { (DOLS) }\end{array}$ \\
\hline \multirow[t]{9}{*}{ Domestic Credit } & Financial Innovation & 0.0738 & 0.0094 & $-0.3044^{* *}$ \\
\hline & Liquidity & $37.9120^{* * *}$ & $35.1475^{* * *}$ & 131.729 \\
\hline & Net interest income & -47.6104 & -81.0290 & 881.659 \\
\hline & Capital adequacy ratio & -18.0180 & -12.7742 & 309.082 \\
\hline & Bank accounts & -0.0026 & $1.06 \mathrm{E}-05$ & 0.0082 \\
\hline & Growth in GDP & $-0.0864 * * *$ & $-0.1030^{* * *}$ & $-0.1720^{* * *}$ \\
\hline & Constant & -10.327 & $-8.8466^{*}$ & -128.6341 \\
\hline & R-sqrd & 0.9165 & 0.9011 & 0.9980 \\
\hline & Adj-R-Sqrd & 0.8965 & 0.8763 & 0.9865 \\
\hline \multirow{9}{*}{$\begin{array}{l}\text { Credit to Individuals } \\
\text { as a proportion of } \\
\text { total credit }\end{array}$} & Financial Innovation & $0.0128^{* *}$ & $0.0180^{* * *}$ & 0.0090 \\
\hline & Bank Accounts & -0.0003 & -0.0004 & -0.0001 \\
\hline & Liquidity & $2.2980 * *$ & $2.3083^{* * *}$ & $-50.372 *$ \\
\hline & Capital Adequacy ratio & -2.1328 & -2.1952 & $71.320^{*}$ \\
\hline & Growth in GDP & $-0.0042^{* *}$ & $-0.0030^{*}$ & -0.0035 \\
\hline & Net Interest Income & -6.9070 & $-9.4443^{*}$ & $-420.637^{* *}$ \\
\hline & Constant & -0.3241 & -0.2436 & $26.480^{* *}$ \\
\hline & R-Sqrd & 0.9165 & 0.9016 & 0.9960 \\
\hline & Adj-R Sqrd & 0.8965 & 0.8770 & 0.9725 \\
\hline
\end{tabular}

$*, * *, * *$ statistically significant at $10 \%, 5 \%$ and $1 \%$, respectively

In terms of control variables, only Liquidity significantly support credit, both domestic and to individuals. This is consistent with the theory that growth in money supply is normally followed by or results in an increase in credit. GDP is negatively related to credit consistent with findings and explanation by (Phakedi, 2014) (Le Roux \& Moyo, 2015) and (Bara \& Mudzingiri, 2016). Other control variables are not statistically significant.

Delivery Channel, Business Expansion and Financial Innovation: Results in Table 6indicate that financial innovation is positively related to bank accounts, implying that financial innovation influences the number of accounts a bank offers. The results are reflective of the developments in the banking sector where-in technology has enabled banks to expand the number of accounts issued. Banks have been making a significant investment in ICT systems to support growth in demand for bank accounts. On other variables, the only GDP positively supports growth in the number of bank accounts. The estimation results also show that financial innovation is not statistically significant in supporting the growth of bank branches. This result is consistent with the notion that financial innovation is actually threatening the existence of branches or expansion of banks through branches as it brings relatively cheaper ways of delivering banking services to outlying areas. In Zimbabwe, a number of the pan- African and international banks have few branches yet they are among the top performers. There has been growth in alternative delivery channels such as agency banking and digital platforms such as mobile banking, internet banking and POS machines. 
Table 6: Bank Accounts, Branches and Financial Innovation

\begin{tabular}{|l|l|l|l|l|}
\hline $\begin{array}{l}\text { Endogenous } \\
\text { variable }\end{array}$ & Exogenous variables & $\begin{array}{l}\text { Ordinary Least } \\
\text { Squares (OLS) }\end{array}$ & $\begin{array}{l}\text { Fully } \\
\text { Least } \begin{array}{c}\text { Modified } \\
\text { Squares } \\
\text { (FMOLS) }\end{array}\end{array}$ & $\begin{array}{l}\text { Dynamic Least } \\
\text { Squares } \\
\text { (DOLS) }\end{array}$ \\
\hline \multirow{4}{*}{ Bank Accounts } & Financial Innovation & $16.884^{* * *}$ & $15.4370^{* * *}$ & 22.1336 \\
\cline { 2 - 5 } & Bank Branches & -1.5165 & -1.1601 & 0.1600 \\
\cline { 2 - 5 } & Growth in GDP & $4.3705^{* * *}$ & $4.0574^{* * *}$ & 5.3836 \\
\cline { 2 - 5 } & Credit to Individuals & 31.569 & 28.1579 & -42.2351 \\
\cline { 2 - 5 } & Constant & $66.9463^{* * *}$ & $66.4096^{* *}$ & 49.5389 \\
\cline { 2 - 5 } & R-sqrd & 0.5919 & 0.5870 & 0.7130 \\
& Adj-R-Sqrd & 0.5315 & 0.5235 & 0.3304 \\
\hline \multirow{5}{*}{ Bank Branches } & Financial Innovation & 0.3151 & 0.3042 & 0.5960 \\
\cline { 2 - 5 } & Bank Accounts & -0.0149 & -0.0151 & -0.0692 \\
\cline { 2 - 5 } & Liquidity & $116.471^{* * *}$ & $129.369^{* *}$ & 72.100 \\
\cline { 2 - 5 } & Growth in GDP & $-0.4128^{* * *}$ & $-0.3931^{* * *}$ & $-0.2749^{* *}$ \\
\cline { 2 - 5 } & Deposit to Assets & -113.351 & -40.5541 & 432.622 \\
\cline { 2 - 5 } & Constant & 34.7329 & -17.9497 & -292.403 \\
\cline { 2 - 5 } & R-Sqrd & 0.8569 & 0.8424 & 0.9920 \\
& Adj-R Sqrd & 0.8293 & 0.8108 & 0.9720 \\
\hline
\end{tabular}

$*, * *, * *$ statistically significant at $10 \%, 5 \%$ and $1 \%$, respectively

Granger Causality Test: Granger causality (Table 7) between bank behaviour and financial innovation is only present in domestic credit and bank branches. In both cases, causality moves from financial innovation to bank behaviour and causality is present in the long run. With domestic credit, causality results imply that in the long run financial innovation causes a reduction in domestic credit $(-0.02556)$. The rationale could be that financial innovation enables banks to increase revenue and earnings from non-funded sources through transactions based revenue and this could push banks to reduce lending, given the increase in NPLs. Indicatively, in the long run, financial innovation seems to support facilitation of banking transactions and not much on the enhancement of credit expansion and quality of credit. Consistent with the result, most fin tech products, including mobile banking that is supported by banks or introduced by banks are not inclined to credit. In respect of bank branches, results show that in the long run, financial innovation causes a reduction $(-0.3237)$ in the bank branches, per 100000 people, in Zimbabwe. The causality result is consistent with theoretical and practical expectations on the effect of technology and innovation on the bank's branch network. Financial innovation is expected to reduce the number of traditional bank branches as banks are using alternative methods to reach to markets. For example, financial innovation has enabled banks to use mobile banking, internet banking, agency banking and other alternative delivery channel to offer banking service. As such, bank behaviour in terms of expansion of branches would be negatively affected by financial innovation in the long run.

Table 7: Granger Causality Tests Bank Behaviour and Financial Innovation

\begin{tabular}{|c|c|c|c|c|}
\hline & \multicolumn{4}{|c|}{ Granger causality test between Credit risk and Financial Innovation } \\
\hline \multirow{7}{*}{$\begin{array}{l}\text { Short- } \\
\text { run } \\
\text { Long- } \\
\text { run }\end{array}$} & Credit risk Dependent & & Financial Innovation Dependent & \\
\hline & $\mathrm{FI}(-1)=\mathrm{FI}(-2)=0$ & & ACL_TL(-1)=ACL_TL(-2) $=0$ & \\
\hline & Wald test Chi-square & 0.3786 & Wald test Chi-square & 0.3037 \\
\hline & $\mathrm{FI}(-1)+\mathrm{FI}(-2)=0.00032$ & & ACL_TL(-1)+ACL_TL(-2) $=0.593$ & \\
\hline & Wald test Chi-square & 0.2347 & Wald test Chi-square & 0.2386 \\
\hline & Granger causality test be & tween D & dit and Financial Innovation & \\
\hline & Domestic Credit Dependen & & Financial Innovation Dependent & \\
\hline Short- & $\operatorname{FI}(-1)=\operatorname{FI}(-2)=0$ & & $\mathrm{CR}(-1)=\mathrm{CR}(-2)=0$ & \\
\hline run & Wald test Chi-square & 3.1142 & Wald test Chi-square & 2.3433 \\
\hline Long- & $F I(-1)+F I(-2)=-0.02556$ & & $\mathrm{CR}(-1)+\mathrm{CR}(-2)=0.1228$ & \\
\hline run & Wald test Chi-square & 2.9176* & Wald test Chi-square & 2.2473 \\
\hline
\end{tabular}




\begin{tabular}{llll}
\multicolumn{5}{c}{ Journal of Economics and Behavioral Studies (ISSN: 2220-6140) } \\
Vol. 10, No. 4, pp. 221-234, August 2018
\end{tabular}

\section{Conclusion and Recommendations}

The paper put forward a discussion on the influence of financial innovation on bank behaviour, focusing on banks' decision regarding risk-taking; branch network and expansion of delivery channels for banking services. Empirical results show that financial innovation influences banks in Zimbabwe to increase credit towards previously high-risk areas. This is enabled by fin tech products that enhance credit monitoring, ensures high reach and access to financial service as well as improved models of credit management that are being introduced by banks. The ability of banks to monitor borrowers due to technology has increased risk appetite of banks. Technology has also enabled expansion of delivery channels by banks, including mobile and agency banking, and also influenced growth in a number of bank accounts. Also, technology enables the provision of low cost and banks accounts with minimal know-your-customer requirements, thus expanding to the unbanked markets. Causality was found to run from financial innovation to bank behaviour, and only in the long run. It, therefore, can be concluded that the behaviour of banks in a low-income country is responsive to technology and financial innovation.

Financial innovation has the capacity to influence activities of banks in a low-income country, particularly in risk management, credit and delivery of banking service. Technology also has the capacity to influence not only the core business of banking, including the products, but also on the structure of banking institutions and delivery channels used by banks, thereby impacting on costs and efficiency. Another deduction is that the impact of innovation in the short run is being limited, presumably by the fact that technology is mostly used to address current challenges faced by the banking sector than for a long-term expansion of the business. The influence and impact of technology in banking increases in the long run and has the potential to transform the banking sector in Zimbabwe. Financial innovation should be at the centre of the driving transformation of the banking sector. Technology and innovations should thus be part of the short, medium to long-term strategies of each banking institutions in Zimbabwe. Notwithstanding the benefits of traditional banking systems, fin tech products and technology should define delivery of banking service and be the basis for revolutionising banking in Zimbabwe. 


\section{References}

Arnaboldi, F. \& Rossignoli, B. (2013). Financial innovation in banking.

Bara, A. \& Mudzingiri, C. (2016). Financial innovation and economic growth: evidence from Zimbabwe. Investment Management and Financial Innovations, 13(2), 65-75.

Bara, A. (2017). Diffusion and adoption of bank financial innovation in Zimbabwe: An external factor analysis. African Journal of Science, Technology, Innovation and Development, 8(4), 357-368.

Bara, A., Mugano, G. \& Le Roux, P. (2016). Financial development and economic growth in the Southern African Development Community (SADC). Studies in Economics and Econometrics, 40(3), 65-93.

Bies, S. S. (2004). Financial Innovation and Effective Risk Management. Financial Services Institute 2004.

Berger, A. N. (2003). The economic effects of technological progress: Evidence from the banking industry. Journal of Money, credit, and Banking, 35 (2), 141-176.

Beyani, M. \& Kasonde, R. (2005). Financial innovation and the importance of modern risk management systems-a case of Zambia. Journal of Finance and Accounting, 3(1), 124-135.

Bilyk, V. (2006). Financial Innovations and the Demand for Money in Ukraine. , s.l.: s.n.

Brandon, K. \& Fernandez, F. (2005). Financial innovation and risk management: An introduction to credit derivatives., s.l.: s.n.

Caporale, G. M., Rault, C. \& Sova, A. (2009). Financial development and economic growth: Evidence from ten new EU Members, s. l.

Cogley, M. (2016). Technology 'driving huge behavioural change' in bank behaviour, s.l.: Independent-Ireland.

Denyes, L. \& Lonie, S. (2016). Digital Financial Services and Risk Management Handbook.

Ernst. \& Young. (2015). Global banking outlook 2015: transforming banking for the next generation of technology reshaping banking, s.l.: EY Global Banking \& Capital Markets.

Frame, W. \& White, L. (2004). Empirical studies of financial innovation: lots of talk, little action?. Journal of Economic Literature, 42(1), 116-144.

Greuning, H. \& Bratanovic, S. B. (2003). Analyzing and Managing Banking Risk: A framework for Assessing Corporate Governance and Financial Risk, Washington DC: World Bank.

Hauke, J. \& Kossowski, T. (2011). Comparison of values of Pearson's and Spearman's correlation coefficients on the same sets of data. Quaestiones Geographicae, 30(2), 87-93.

Harle, P. et al., n.d. 8. Härle, P., Havas. A., Kremer. A., Rona. D. \& Samandari., H. (n.d). The future of bank risk management. McKinsey Working Papers on Risk, s.l.: McKinsey Working Papers on Risk.

Hyde, P., Liebert, T. \& Wackerbeck, P. (2009). A comprehensive risk appetite framework for banks, s.l.: Leading Research, Booz\&Co.

Iman, N. (2011). Innovation in financial services: a tale from e-banking development in Indonesia. International Journal of Business Innovation and Research, 8(5), 498-522.

Irungu, M. (2014). The Effects of Financial Innovations on Credit Risk Management of Commercial Banks in Kenya, s.l.: Doctoral Dissertation, School Of Business,University of Nairobi.

Jenkinson, N., Penalver, A. \& Vause, N. (2008). Financial innovation: what have we learnt?, s.l.: s.n.

Jolliffe, I. T. (2002). Graphical representation of data using principal components. Principal Component Analysis, 78-110.

Kamra, S. (2014). Digital Transformation in Banking - The Future of Banking, Happiest Minds Technologies, s.l.: s.n.

Kero, A. (2013). Banks' risk-taking, financial innovation and macroeconomic risk. The Quarterly Review of Economics and Finance, 53(2), 112-124.

Khayrallah, A. et al. (2015). Technology \& Banking.. Applied Innovation Review, 23(1).

Laeven, L. R. L. \& S, M. (2015). Financial innovation and endogenous growth. Journal of Financial Intermediation, 24(1), 1-24.

Le Roux, P. \& Moyo, C. (2015). Financial liberalisation and economic growth in the SADC, s.l.: Economic Research Southern Africa (ERSA) .

Lerner, J. \& Tufano, P. (2011). The consequences of financial innovation: a counterfactual research agenda. Annual Review Financial Economics, 3(1), 41-85.

Lewis, M. \& Mizen, P. (2000). Monetary economics. , s.l.: OUP Catalogue..

Llewellyn, D. T.(2009). Challenges for Monetary Policymarkersin Emergency Markets, I.

Masih, R. \& Masih, A. M. (1996). Stock-Watson dynamic OLS (DOLS) and error-correction modelling approaches to estimating long-and short-run elasticities in a demand function: new evidence and 


\section{Journal of Economics and Behavioral Studies (ISSN: 2220-6140)}

Vol. 10, No. 4, pp. 221-234, August 2018

methodological implications from an application to the demand for coal in mainland China.. Energy Economics, 18(4), 315-334.

Matthews, K. \& Thompson, J. (2008). The Economics of Banking. second ed. s.l.:Chichester: Wiley,.

Norden, L., Buston, C. \& Wagner, W. (2014). Financial innovation and bank behaviour: Evidence from credit markets. Journal of Economic Dynamics and Control, 43, 130-145.

Norden, L., Buston, C. \& Wanger, W. (2014). Financial innovation and bank behavior: Evidence from credit markets. Journal of Economic Dynamics and Control, 43, 130-145.

Phakedi, M. (2014). Financial sector development and economic growth in SADC. A research paper to be submitted to the Committee of Central Bank Governors in SADC.

Phillips, P. \& Hansen, B. E. (1990). Statistical inference in instrumental variables regression with I (1) processes. The Review of Economic Studies, 57(1), 99-125.

Phillips, P. C. (1995). Fully modified least squares and vector auto-regression. Journal of the Econometric Society, 1023-1078.

Santomero, A. M. \& Trester, J. J. (1998). Financial innovation and bank risk-taking. Journal of Economic Behaviour \& Organization, 35(1), 25-37.

Solans, E. (2003). Financial innovation and monetary policy. In speech at the 38th SEACEN Governors Conference, Manila, February.. s.l., s.n.

Stock, J. H. \& Watson, M. W. (1993). A simple estimator of cointegrating vectors in higher order integrated systems. Econometrica: Journal of the Econometric Society, 783-820.

RBZ. (2017). Monetary Policy Statement, Harare: Reserve Bank of Zimbabwe.

RBZ. (2010). Monetary Policy Statement, Harare: Reserve Bank of Zimbabwe.

RBZ. (2013). Monetary Policy Statement, Harare: Reserve Bank of Zimbabwe.

Utterback, J. \& Afuah, A. (1998). The dynamic 'diamond': a technological innovation perspective.. Economics of Innovation and New Technology. 